\title{
Starch and Cellulose as Fuel Sources for Low Temperature Direct Mode Fuel Cells
}

\author{
J.-P. Spets ${ }^{*, 1}$, Y. Kiros ${ }^{2}$, M. A. Kuosa ${ }^{1}$, J. Rantanen ${ }^{3}$, J. Sallinen ${ }^{1}$, M. J. Lampinen ${ }^{1}$ and K. Saari ${ }^{1}$ \\ ${ }^{1}$ Helsinki University of Technology, Laboratory of Applied Thermodynamics, P.O. Box 4400, FI-02150 TKK, Finland \\ ${ }^{2}$ Royal Institute of Technology-KTH, Department of Chemical Engineering and Technology, S100-44 Stockholm, \\ Sweden \\ ${ }^{3}$ Oy Hydrocell Ltd, Minkkikatu 1-3, FI-04430 Järvenpää, Finland
}

\begin{abstract}
This paper is a study about a direct mode fuel cell with a near-neutral-state and alkaline electrolytes. The aim of study was to develop a fuel cell, which operates directly by mixing the fuel with the electrolyte. This arrangement helps to avoid inserting membranes and additional bacterial cultures in fuel cell. The target is also to create a fuel cell with a capacity of few $\mathrm{mWcm}^{-2}$ with the starch as a fuel. Also, glucose and sorbitol have been tested as fuel for the fuel cell.
\end{abstract}

Keywords: Direct mode fuel cell, neutral and alkaline electrolyte, catalyst materials, starch, glucose and sorbitol.

\section{INTRODUCTION}

The complex storage of carbohydrates for the nature such as starch and cellulose are attractive candidates of fuels for fuel cell, because they are ready to use in fuel cell with less processing steps than e.g. bio-ethanol requires. A glucose as the fuel for the fuel cell is also of great importance, because glucose can be produced easily through hydrolysis from starch and cellulose [1]. In this study, a direct mode fuel cell, in which fuel and electrolyte are mixed with each others, is tested. The fuels in this starting point of our research are starch $\left(\mathrm{C}_{12} \mathrm{H}_{20} \mathrm{O}_{10}\right)_{\mathrm{n}}$, glucose $\left(\mathrm{C}_{6} \mathrm{H}_{12} \mathrm{O}_{6}\right)$ and sorbitol $\left(\mathrm{C}_{6} \mathrm{H}_{14} \mathrm{O}_{6}\right)$. Sorbitol (i.e. polyoil) is produced by reducing glucose. It is interesting to compare these different kinds of saccharides, especially how they work as a fuel in fuel cells. The target is to produce both effective and simple direct mode biofuel cell with a near-neutral-state or an alkaline electrolyte with a moderate electric power production capacity of few $\mathrm{mWcm}^{-2}$. The near-neutral-state electrolyte is of interest for two reasons. Firstly, the $\mathrm{pH}$ of the electrolyte would be near the $\mathrm{pH}$ of liquid in living cells. Secondly, the neutral electrolyte would enable good corrosion resistance of catalyst materials. There also exist other kinds of applications that utilise enzymes or bacterial culture for reforming of bio fuels in fuel cell applications [2, 3]. Concerning the application of glucose or other carbohydrates, if the fuels for fuel cell operation were dissolved in an electrolyte, there would be no need for auxiliary reforming equipment or additional bacterial cultures. Also, a direct operation mode for these fuels in fuel cells would not need any proton selective membranes as the PEM fuel cell does $[4,5]$. In the development of the selected bioorganic fuel cell, there is a target of producing oxidation reactions in ionic form in the liquid phase by increasing the oxidation number of the reaction

*Address correspondence to this author at the Helsinki University of Technology, Laboratory of Applied Thermodynamics, P.O. Box 4400, FI-02150 TKK, Finland; E-mail: jukka-pekka.spets@tkk.fi products. This would enable a high electronic yield and electric power production from one molecule of bioorganic molecule. In earlier studies with glucose or other carbohydrates as a fuel in fuel cells, this has been achieved using metallic catalysts in neutral, alkaline or acidic electrolytes [4-11]. When glucose is concerned, the oxidation reaction is believed to take place to only a limited degree, and the total yield of electrons from the molecule has only been two electrons from 24 available electrons $[6,10]$. In studies regarding direct bioorganic oxidations, the anodic catalyst materials were composed of different Pt alloys [4, 8-11]. In this study, an anode catalyst of Pt-Pd and a combined cathode catalysts of cobalt porphyrin complex CoTPP and of spinel $\mathrm{MnCo}_{2} \mathrm{O}_{4}$ are being tested.

\section{EXPERIMENTAL}

In our tests the catalyst loadings of the anode electrode were about $2.46 \mathrm{mgcm}^{-2}$ for both the Pt and $\mathrm{Pd}$ bimetallic combinations (both in concentrations of $10 \%$ on carbon) in a weight ratio of 1:1. The catalyst loadings of the cathode electrode contained a catalyst loading of 3.15 $\mathrm{mgcm}^{-2}$ of CoTPP in concentration of $18 \%$ on carbon and of $17.5 \mathrm{mgcm}^{-2}$ of $\mathrm{MnCo}_{2} \mathrm{O}_{4}$. The anode electrode consisted of a single-layer structure without diffusion material. The cathode electrode was of the double-layer type with both the active catalysts and the diffusion layers. The electrodes were sintered at $350{ }^{\circ} \mathrm{C}$. The geometric areas of both electrodes were $200 \mathrm{~cm}^{2}$. The Pt-Pd catalyst was a commercial grade purchased from Johnson-Matthey. The CoTPP and the $\mathrm{MnCo}_{2} \mathrm{O}_{4}$ catalysts were commercial products obtained from Oy Hydrocell Ltd.

The test routine in all the tests was as follows: 1). Preparation of the aqueous alkaline (i.e. $2 \mathrm{M}$ potassium hydroxide $\mathrm{KOH}$ by Sigma Aldrich) or the near-neutral-state (i.e., $1 \mathrm{M}$ potassium phosphate monobasic $\mathrm{KH}_{2} \mathrm{PO} 4$ (by Fluka) with adding $\mathrm{KOH}$ to set the $\mathrm{pH}$ value at 7.4) electrolyte solution with glucose (glucose anhydrous, Oriola), starch (86 wt$\%$ corn starch, Unilever) or sorbitol (Neosorb P. 60, 
Roquette). 2). Addition of the solution in the cell. 3). Measurement of the open circuit voltage (OCV) in room temperature (RT) and after heating the electrolyte up to temperature of $51{ }^{\circ} \mathrm{C}$ until steady-state is attained. 4. After reading the values of the $\mathrm{OCV}$, the current versus voltage was recorded for each type fuel cell.

\section{RESULTS AND DISCUSSION}

The results showed that when using the near-neutral state electrolyte in the fuel cell, the power output was found to be negligible, i.e., the current densities and voltages were found to be too low. Therefore, the test results in this study mainly deal with the alkaline electrolyte.

Fig. (1) shows the polarization curves having glucose, sorbitol and starch as the fuel in the alkaline electrolyte $(2 \mathrm{M}$ $\mathrm{KOH})$. Both glucose and sorbitol were added in the fuel cell in concentrations of $1 \mathrm{M}$. Due to the imprecise nature of determining the exact molecular weight of starch, starch with a weight concentration of $10 \mathrm{~g} / \mathrm{l}$ was added to the electrolyte for comparisons with the other types of fuels.

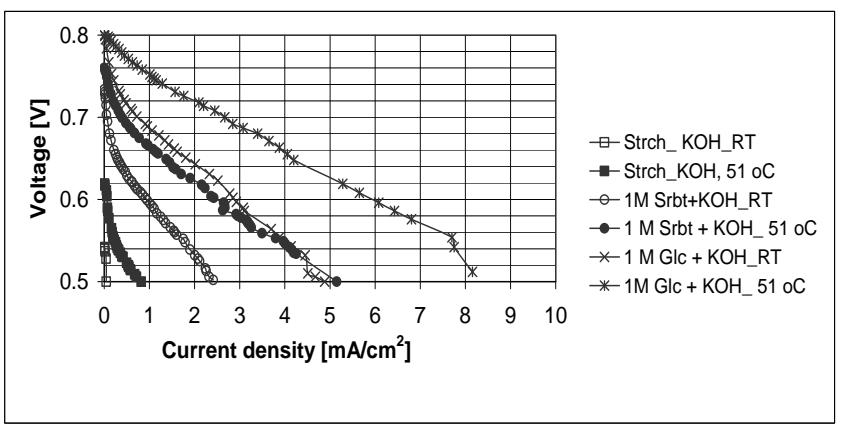

Fig. (1). Polarization curves for the direct mode fuel cell with glucose (Glc), sorbitol (Srbt) and starch (Strch) as a fuel in an alkaline (aqueous $2 \mathrm{M} \mathrm{KOH}$ ) electrolyte. Anode catalyst Pt-Pd, and the cathode catalysts CoTPP and $\mathrm{MnCO}_{2} \mathrm{O}_{4}$. Tests at two temperatures. $\mathrm{RT}=$ room temperature.

The corresponding OCV values in Fig. (1) with respect to the electrolytes and the concentrations of the fuels at two different temperatures are as follows: Glucose $(\mathrm{RT})=0.80$ $\mathrm{V}$, glucose $\left(51{ }^{\circ} \mathrm{C}\right)=0.80 \mathrm{~V}$, sorbitol $(\mathrm{RT})=0.73 \mathrm{~V}$, sorbi$\operatorname{tol}\left(51{ }^{\circ} \mathrm{C}\right)=0.76 \mathrm{~V}$, starch $(\mathrm{RT})=0.54 \mathrm{~V}$ and $\operatorname{starch}\left(51{ }^{\circ} \mathrm{C}\right)=$ $0.62 \mathrm{~V}$.

From the results shown in Fig. (1), it can be seen that glucose provides the highest power densities among the other types of bioorganic fuels. Raising the electrolyte temperature improves the current density versus the voltage values for all types of fuels. The current density values were found to be higher than the findings in earlier report [5] in which microbial fuel cell with membrane for starch was studied. The starch molecule was not utilized as the other fuels because hydrolysis didn't take place. By heating up the electrolyte temperature, sorbitol was found to have as equal current density as glucose at room temperature. Therefore, the research for starch and cellulose as a fuel for fuel cells is interesting for direct electrochemical oxidation and especially for glucose, as it is the product of hydrolysis of both types of storage carbohydrates in the nature.
Concerning the poor results with the near-neutral electrolyte, it is evident that the anode catalyst Pt-Pd is active in alkaline electrolyte. It is reported earlier, that $\mathrm{Ni}$ catalyst is considered active anode catalyst for the electro catalytic oxidation of carbohydrates such as primary alcohols in alkaline solutions [12]. Thus, both $\mathrm{Pt}$ and $\mathrm{Ni}$ catalysts require an $[\mathrm{OH}]$ - ion concentration in the electrolyte high enough to work effectively in the electro-oxidation of carbohydrates. Selective catalysts are therefore being sought for in order to operate in near-neutral state electrolytes. The differences in operational capacities of fuel cells with near-neutral state and alkaline electrolytes are apparent due to the ionic conductivities and properties of the catalysts.

Concerning the electrochemical oxidations of the bioorganic materials, the yield of electrons from available electrons per one molecule of glucose is believed to be low. Further studies using cyclic voltammetry and rotating disc electrodes analyses have to be made in order to find out oxidation-reductions as well as the number of electrons exchanged. Any presentation of the poisoning effect of the catalyst materials by the reaction products, during the electrochemical oxidation reactions of the selected bioorganic materials cannot be given either. Oxidation of glucose, which is a hydrolysis product of starch and cellulose, Pt catalyst, is reported to be poisoned by gluconic acid in near neutral electrolytes [13]. Furthermore, Pt catalyst poisoning during electro-oxidation of glucose is said to be inhibited by alloying it with other materials such as $\mathrm{Sn}$ and $\mathrm{Pb}$ [11].

\section{CONCLUSIONS}

In this study glucose, sorbitol and starch were tested mixed in the near-neutral-state and in alkaline electrolytes in the direct mode fuel cell. As a result of these studies, we found that glucose in aqueous alkaline electrolyte produced the highest power output in the test fuel cells. Therefore, research on electrochemical oxidation of starch and cellulose will be in fact a research on glucose electro-oxidation, due to the fact that both starch and cellulose have to be treated in a way before they can be successfully operated as a fuel in a fuel cell. By hydrolysis of starch and cellulose, glucose is formed. However, both starch and cellulose are interesting candidates as a fuel in fuel cell, because they need less processing steps compared to other fuel types, before supplying to the fuel cell. The direct mode low temperature fuel cells with electric power production capacity of few $\mathrm{mWcm}^{-2}$ with starch and cellulose as fuels is possible through research on active catalytic materials.

\section{REFERENCES}

[1] Dhepe, P. L.; Fukuoka, A. Cracking of cellulose over supported metal catalysts. Catal. Surv. Asia, 2007, 11, 186-191.

[2] Liu, Y.; Dong, S.; A biofuel cell with enchanced power output by grape juice. Electrochem. Commun., 2007, 9, 1423-1427.

[3] Rabaey, K.; Verstraete, W. Microbial fuel cells: novel biotechnology for energy generation. Trends Biotechnol., 2005, 25, 291-298.

[4] von Stetten, F.; Kerzenmacher, S.; Lorenz, A.; Chokkalingam V.; Miyakava, N.; Zengerle, R.; Ducree J. A one-compartment, direct glucose fuel cell for powering long-term medical implants In MEMS. Turkey, 2006, pp. 934-937.

[5] Niessen, J.; Schröder, U.; Scholz, F. Exploiting complex carbohydrates for microbial electricity generation - a bacterial fuel cell operating on starch. Electrochem. Commun., 2004, 6, 955-958.

[6] Verma, A.; Basu, S. Direct alkaline fuel cell for multiple liquid fuels: Anode electrode studies. J. Power Sources, 2007, 174, 180185. 
[7] Verma, A.; Basu, S. Direct use of alcohols and sodium borohydrides as fuel in an alkaline fuel cell. J. Power Sources, 2005, 145, 282-285.

[8] Li, J.; Moore, C.; Kohl, P. A. Investigation of acidic methanol solution as a fuel for microchannel fuel cells. J. Power Sources, 2004, 138, 211-215.

[9] Yao, S. J.; Appleby, A. J.; Geisel, A.; Cash, H. R.; Wolfson, S. K. Jr. Anodic oxidation of carbohydrates and their derivatives in neutral saline solution. Nature, 1969, 224, 921-922.

[10] McKinley, J.; McHale, F. N.; Hughes, P.; Reid, C.N.; McHale, A.P. Production of electrical energy from carbohydrates using a transition metal-catalysed liquid alkaline fuel cell. Biotechnol. Lett., 2004, 26, 1771-1776.
[11] Kelly, M. J.; Ingersoll, D.; Steen, W. A.; Cocker, E. N.; Abraham, I. C.; Miller, J. E. Electochemical oxidation of D-glucose at noble metal and binary metal catalyst for fuel cell applications. Abs. 736, $205^{\text {th }}$ Meeting. The Electrochemical Society, Inc. (C) 2004, http://www.electrochem.org/dl/ma/205/pdfs/0736.PDF.

[12] Golabi, S. M.; Nozad, A. Electrocatalytic oxidation of methanol on a nickel-porphyrin IX complex modified glassy carbon electrode in alkaline medium. Electroanalysis, 2004, 3, 199-209.

[13] Karski, S.; Paryjczak, T; Witonska, I. Selective oxidation of glucose to gluconic acid over bimetallic Pd-Me catalysts $(\mathrm{Me}=\mathrm{Bi}, \mathrm{Tl}$, Sn, Co). Kinet. Catal., 2003, 44, 678-682.

(C) Spets et al.; Licensee Bentham Open.

This is an open access article licensed under the terms of the Creative Commons Attribution Non-Commercial License (http://creativecommons.org/licenses/by-nc/3.0/) which permits unrestricted, non-commercial use, distribution and reproduction in any medium, provided the work is properly cited. 